- Fábio Lambertini Tozzi

- Erasmo Simão da Silva

- Fernando Campos

- Henrique 0 scar de Azevedo

Fagundes $\mathrm{N}$ eto

- Marcos Lucon

- Renato M icelli Lupinacci

\section{Primary aortoenteric fistula related to septic aortitis}

\author{
U niversity H ospital, U niversidade de São Paulo, São Paulo, B razil
}

ABSTRACT

CONTEXT: Primary a ortoenteric fistulas usually result from erosion of the bowel wall due to an associated abdominal aortic aneurysm. A few patients have been described with other etiologies such as pseudoaneurysm originating from septic aortitis caused by Salmonella.

OBJECTIVE: To present a rare clinical case of pseudoaneurysm caused by septic aortitis that evolved into an aortoenteric fistula.

CASE REPORT: A 65 -year-old woman was admitted with Salmonella bacteremia that evolved to septic aortitis. An aortic pseudoaneurysm secondary to the aortitis had eroded the transition between duodenum and jejunum, and an aortoenteric fistula was formed. In the operating room, the affected aorta and intestinal area were excised and an intestine-to-intestine anastomosis was performed. The aorta was sutured and an axillofemoral bypass was carried out. In the intensive care unit, the patient had a cardiac arrest that evolved to death.

KEY WORDS: Septic a ortitis. Primary a ortoenteric fistula. Aneurysm. Pseudoaneurysm.
......... INTRODUCTION

Aortoenteric fistulas are classified as primary ${ }^{1}$ and secondary, ${ }^{2}$ (after aortic repair by means of an arterial prosthesis). This condition involves arterial rupture and infection of vascular areas. ${ }^{3}$ Primary fistulas are in most cases $(90 \%)^{4}$ theresult of erosion of the bowel wall, caused by abdominal aortic aneurysm. Septic aortitis is also one of the most challenging problems that confront the vascular surgeon. Transient bacteremia allows lodgment of bacteria on the inner arterial surface and permits the formation of an aneurysm or false aneurysm. Primary fistulas can develop as a result of this pathogenic process. ${ }^{4 \cdot 9}$ The aim of this work is to present the case report of a patient with a pseudoaneurysm due to Salmonella aortitis, which originated an aortoenteric fistula.

\section{CASE REPORT}

A 65-year-old black woman with a twenty-year history of diabetes mellitus was admitted with diffuse abdominal pain and fever. The abdomen was distended without palpable abdominal masses. H er blood pressure was $220 \times 120 \mathrm{mmH}$, temperature $38.2^{\circ} \mathrm{C}$, and the white blood cell count was 23,000 leukocytes per $\mathrm{mm}^{3}$. Abdominal radiography and ultrasonography were unremarkable. A blood culture grew Salmonella nontyphymurium, and she was treated intravenously with ceftriaxone and discharged on the $11^{\text {th }}$ day. Cerriaxone was substitute for oral amoxicillin.

Thirty days after discharge, the patient returned with diffuse abdominal pain, associated with fever ( $39 \stackrel{\circ}{\circ}$ ). Physical examination brought into evidence a pulsatile, epigastric and periumbilical abdominal mass. Bmode ultrasound scanning showed an infrarenal aortic aneurysm, $5.7 \mathrm{~cm}$ in diameter. W hile waiting for abdominal tomography (CT scan), to make an examination of the aortic dilation, the patient had three hematemesis episodes. Endoscopy was repeated threetimes and only in thelast of these was a pulsatile lesion shown in the fourth portion of the duodenum. In order to analyze the anatomy of the aneurysm, an emergency CT scan was performed, which displayed a large pseudoaneurysm with gas close to the arterial wall (Figure 1).

Eighteen hours after the first bleeding, the patient was submitted to a midline laparotomy, which revealed a large retroperitoneal hematoma densely adhering to the duodenum-jejunum transition. After proximal aortic control the fistula was closed off and a large intestinal defect was detected. The affected intestinal area was removed and intestine-to-intestine an astomosis was performed. The infected aorta and the large hematoma were excised, and the proximal aorta and iliac common arteries were oversewn. A right axillobifemoral bypass graft with prosthesis was constructed.

Eight hours after the end of the surgery, the patient had cardiac arrest and was unresponsive to resuscitative maneuvers. Necropsy could not identify the cause of death and a metabolic origin was considered. The infrarenal aortic specimen exhibited the presence of some fatty streaks, but there was 
no massive atherosclerotic disease.

$$
\text { DISCUSSION }
$$

Classifications used for describing arterial infection include several different names, such as mycotic aneurysm, infected aneurysm, aortitis, cryptogenic aortitis, bacterial aortitisand microbial arteritis. ${ }^{2} \mathrm{M}$ icrobial arteritis is an infectious process that attacks a non-aneurysmal artery and develops an aneurysm or arterial rupture with pseudoaneurysm² (Figure 2). 0 ur patient presented microbial arteritiscaused by Salmonella. Fever, abdominal distension and pain were some of the common aortitis diagnostic findings in our patient. When aortic infection leads to aneurysm or pseudoaneurysm formation, there may be a pulsatile mass present. In theinitial phase of the aortitis, there may not be any remarkable findings from either ultrasound or tomography. In our clinical case, the first ultrasound showed a normal aorta, but a large pseudoaneurysm was detected one month later.

Standardized diagnosis of primary fistulas, as well as the management of such patients, is especially difficult ${ }^{10}$ because primary fistulas are not frequent (Table 1). W hen the primary fistula has an etiology other than an aneurysm, such as aortitis, ${ }^{4-8}$ or when it is idiopathic, ${ }^{16-19}$ diagnosis difficultiesincrease. For two-thirds of the patients, the diagnosis is made in the operating room ${ }^{15}$ (Table 2). The classic trio of abdominal pain, palpable mass and gastrointestinal bleeding only occurs in $6 \%$ to $12 \%$ of patients. ${ }^{3,4}$

W ith regard to aortoenteric fistula, hematemesis and melena form the most com- mon symptoms ( $32 \%$ to $78 \%$ ). ${ }^{13,20}$ W hen the etiology is an aortic aneurysm, a palpable mass can be found in $25 \%$ to $70 \%$ of the patients. ${ }^{1,4,13}$

Endoscopy is essential. H owever, it has the potential risk of inducing massivehemorrhage by dislodging fresh thrombusin the fistula. ${ }^{16,17}$ In our case, the endoscopy was repeated in order to achieve a diagnosis. We believed that making the patient undergo a laparotomy without diagnosis would behazardous. Rarely can angiography demonstrate the fistula, as the bleeding is usually not active at the time of the examination. ${ }^{16,18}$

Theoutcomewill depend upon the timeliness of diagnosis, the patient's general state, the degree of contamination, and the anatomical site of the aorta involved. The conventional treatment of infrarenal aortic infection includes primary intestinal suture or resection and intestinal anastomosis, excision and drainage of infection with the oversewing of the infrarenal aorta, combined with axillofemoral bypass grafting. ${ }^{21} \mathrm{~T}$ healternative of extra anatomical grafting is used in situations where the above cannot be performed, i.e. in infectious aneurysms of the aorta that involve the visceral branches. ${ }^{22}$ In these cases, the synthetic prosthesis is placed

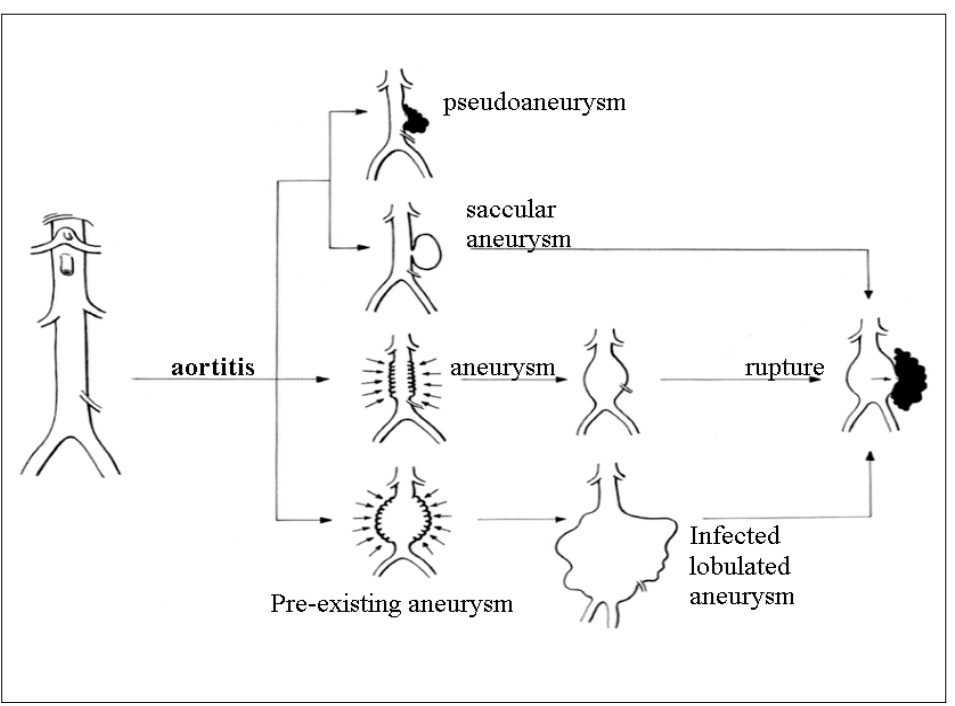

Figure 2. Infectious aortitis could affect a normal aorta or aneurysmal aorta with different forms of presentation. in situ. In the infrarenal aortic segment, in the absence of gross pus at the site of the fistula, in situ prosthesis grafting could be performed. ${ }^{23,} 24$

Alternative reconstruction methods have been proposed and consist of in situ replacement with an antibiotic-bonded prosthesis, ${ }^{25}$ homografts, ${ }^{26}$ and reconstruction with femoral veins. ${ }^{27}$ Additional maneuvers to prevent prosthesis infection include the use of viable pedicles of the greater omentum between aortic grafts and intestinal suture, ${ }^{23}$ and prolonged antibiotic therapy. ${ }^{24}$ In our case, the option
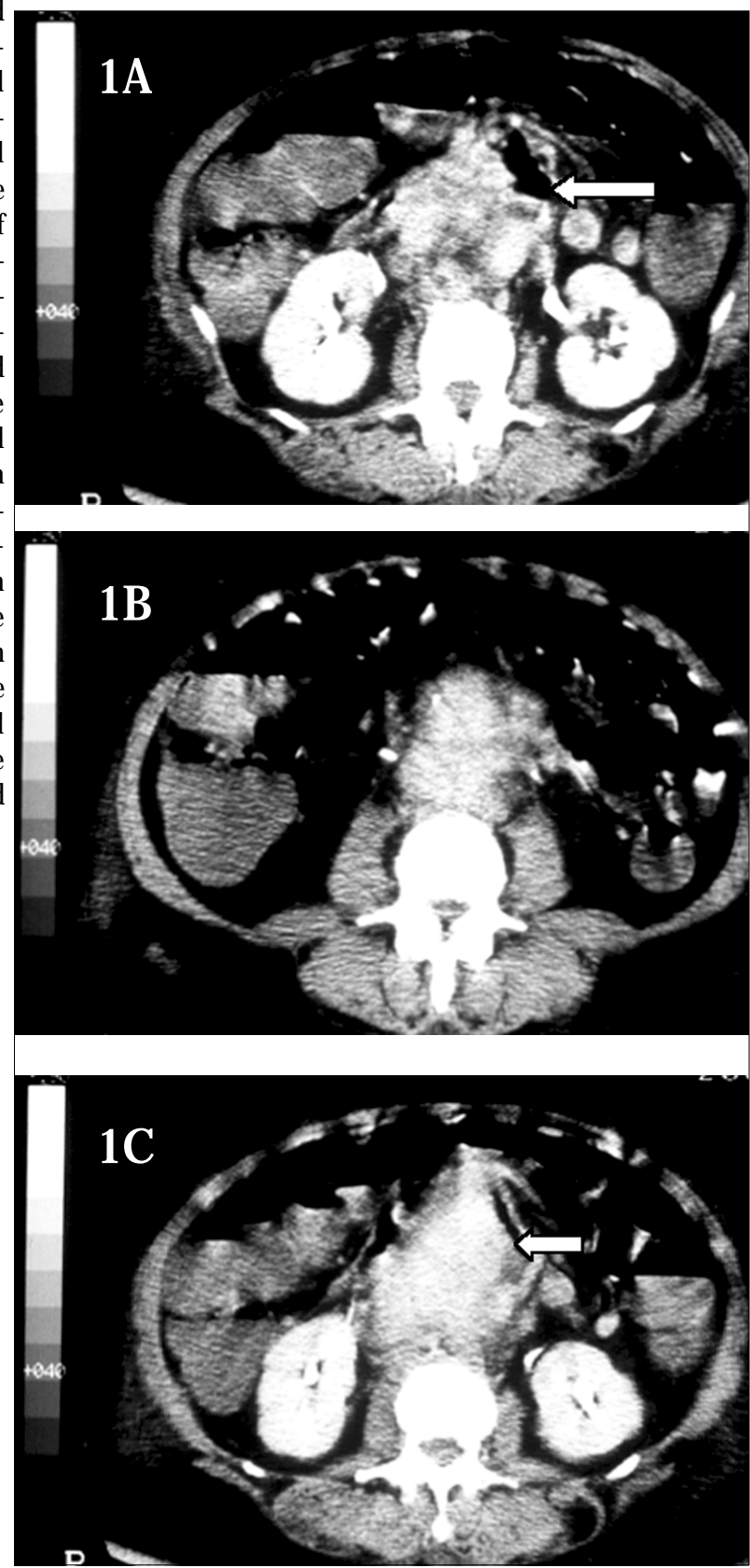

Figure 1. CT scan reveals a large pseudoaneurysm with air close to aortic wall (arrows). 
was for extra-anatomical reconstruction, owing to the high risk and difficulty of carrying out in situ prosthesisplacement on an infected, friable aorta.
Early diagnosis and aggressive surgical treatment are the best ways to achieve succesfful results in aorta-infected patients. The multifactorial features of this condition rule out one singleapproach, and themedical team must have knowledge of several forms for its presentation, aswell as several optionsfor dealing with this malady.

\section{Table 1. Samples of patients affected by primary aortoenteric fistula from different} literature reviews, with number of operated patients and surgical results

\begin{tabular}{|c|c|c|c|c|}
\hline Literature review & Number of cases reviewed & Number of patients operated & Patients that survived & Mortality \\
\hline Reckless et al., ${ }^{11} 1972$ & 131 & 20 & 8 & $60 \%$ \\
\hline Brenowitz et al., ${ }^{12} 1976$ & 100 & 20 & 10 & $50 \%$ \\
\hline Reiner et al., ${ }^{13} 1978$ & 112 & 33 & 15 & $55 \%$ \\
\hline Daugherty et al., ${ }^{14} 1979$ & 49 & 25 & 14 & $44 \%$ \\
\hline Sweeney et al., 1984 & 118 & 33 & 21 & $36 \%$ \\
\hline Calligaro et al., ${ }^{4} 1992$ & 226 & 82 & 44 & $46 \%$ \\
\hline Dossa et al., ${ }^{15} 1994$ & 65 & 57 & 36 & $37 \%$ \\
\hline Voorhoeve et al., ${ }^{3} 1996$ & 243 & 54 (starting from 1984) & 29 & $46 \%$ \\
\hline
\end{tabular}

Table 2. Characteristics of patients with primary aortoenteric fistula due to aortitis without previous aortic aneurysm

\begin{tabular}{|c|c|c|c|c|c|c|c|}
\hline Authors/year & Gender & Age & Clinical findings & Diagnostic approach/ fistula site & Etiological agent & Treatment & Outcome \\
\hline M clntyre et al., ${ }^{6} 1981$ & M & 73 & $\begin{array}{l}\text { Diabetes, low back } \\
\text { pain, fever, } \\
\text { pulsatile mass }\end{array}$ & $\begin{array}{l}\text { Laparotomy: } \\
3^{\text {rd }} \text { portion } \\
\text { of duodenum }\end{array}$ & Arizona hinshawii & $\begin{array}{l}\text { Aortic } \\
\text { division } \\
+ \text { axillo- } \\
\text { bifemoral } \\
\text { bypass }\end{array}$ & $\begin{array}{l}\text { Satisfactory } \\
\text { after } 9 \text { months }\end{array}$ \\
\hline Goldbaum et al., 1986 & M & 75 & $\begin{array}{l}\text { Abdominal } \\
\text { pain, fever, } \\
\text { hematemesis }\end{array}$ & $\begin{array}{l}\text { Laparotomy: } \\
3^{\text {rd }} \text { portion of } \\
\text { duodenum }\end{array}$ & $\begin{array}{l}\text { Mycobacterium } \\
\text { tuberculosis }\end{array}$ & $\begin{array}{l}\text { Dacron graft } \\
\text { in situ }\end{array}$ & $\begin{array}{l}\text { Satisfactory } \\
\text { after } 20 \text { years }\end{array}$ \\
\hline Morrow et al., ${ }^{8} 1987$ & $\mathrm{~F}$ & 32 & $\begin{array}{l}\text { Abdominal } \\
\text { pain, back } \\
\text { pain, hematemesis }\end{array}$ & $\begin{array}{l}\text { Laparotomy: } \\
4^{\text {th }} \text { portion of } \\
\text { duodenum }\end{array}$ & $\begin{array}{c}\text { Salmonella } \\
\text { enteritidis }\end{array}$ & $\begin{array}{l}\text { Dacron graft } \\
\text { in situ }\end{array}$ & $\begin{array}{l}\text { Satisfactory } \\
\text { after } 3 \text { years }\end{array}$ \\
\hline W heeler et al., ${ }^{5} 1992$ & M & 63 & $\begin{array}{l}\text { Melena, } \\
\text { abdominal } \\
\text { pain, pulsatile } \\
\text { mass }\end{array}$ & $\begin{array}{l}\text { Laparotomy: } \\
4^{\text {th }} \text { portion } \\
\text { of duodenum }\end{array}$ & $\begin{array}{l}\text { Mycobacterium } \\
\text { tuberculosis }\end{array}$ & $\begin{array}{l}\text { Dacron graft } \\
\text { in situ }\end{array}$ & $\begin{array}{l}\text { Satisfactory } \\
\text { after } 7 \text { years }\end{array}$ \\
\hline Calligaro et al., ${ }^{6} 1992$ & $\mathrm{~F}$ & 60 & $\begin{array}{l}\text { Abdominal } \\
\text { pain, fever }\end{array}$ & $\begin{array}{l}\text { Laparotomy: } \\
3^{\text {rd }} \text { portion } \\
\text { of duodenum }\end{array}$ & $\begin{array}{l}\text { Streptococcus } \\
\text { viridans }\end{array}$ & $\begin{array}{l}\text { Aortic } \\
\text { division }\end{array}$ & $\begin{array}{l}\text { Death in the } \\
\text { operating } \\
\text { room }\end{array}$ \\
\hline
\end{tabular}


1. Sweeney M S, G adaczT R. Primary aortoduodenal fistula: manifestation, diagnosis, and treatment. Surgery 1984;96:492-7.

2. Perler BA, Ernst CB. Infected aneurysms. in: Veith FJ, H obson RW, W illiams RA, W ilson SE, editors. Vascular surgery: principles and practice. N ew York: M CGraw-H ill; 1994:589-608.

3. Voorhoeve R, M oll FL, Letter JAM, et al. Primary aortoenteric fistula: report of eight new cases and review of the literature. Ann Vasc Surg 1996;10:40-8.

4. Calligaro KD, Bergen WS, Savarese RP, et al. Primary aortoduodenal fistulae due to septic aortitis. J Cardiovasc Surg 1992;33:192-8.

5. Wheeler WE, H anksJ, Raman VK. Primary aortoenteric fistulas. Am Surg 1992;58:53-4.

6. M clntyre KE, M alone JM, Richards $E$, et al. Mycotic aortic pseudoaneurysm with aortoenteric fistula caused by Arizona hinshawii. Surgery 1982;91:173-7.

7. Goldbaum TS, Lindsay J Jr, Levy C, et al. Tuberculous aortitis presenting with an aortoduodenal fistula: a case report. Angiology 1986;37:519-23.

8. Morrow C, Safi H, Beall AC. Primary aortoduodenal fistula caused by Salmonella aortitis. J Vasc Surg 1987;6:415-8.

9. O z M C, Brener BJ, Buda JA, et al. A ten-year experience with bacterial aortitis. J Vasc Surg 1989;10:439-49.

10. VoorhoeveR, M oll FL, Bast TJ.T heprimary aortoenteric fistula in the N etherlands: the unpublished cases. Eur J Vasc Endovasc
Surg 1996;11:429-31

11. Reckless JPD, M cC oll I, Taylor GW. Aortoenteric fistulae: an uncommon complication of abdominal aortic aneurysms. $\mathrm{Br}$ J Surg 1972;59:458-60.

12. Brenowitz JB, Williams CD. Successful repair of primary aortoduodenal fistula. Am Surg 1976;42:265-7.

13. Reiner M A, Brau AS, Schanzer H. Primary aortoduodenal fis tula: case presentation and review of literature. Am J Gastroenterol. 1978;70:292-7.

14. Daugherty M, Shearer GR, Ernst CB. Primary aortoduodenal fistula: extra-anatomic vascular reconstruction not required for succesful management. Surgery 1979;86:399-401.

15. D ossa CD, Pipinos I, Shepard AD, et al. Primary aortoenteric fistula. Ann Vasc Surg 1994;8:113-20.

16. FrizelleFA, $\mathrm{H}$ ung $\mathrm{N} A, \mathrm{H}$ eslop J $\mathrm{H}$, et al. O bscure gastrointestinal bleeding: idiopathic aortoduodenal fistula. J R Coll Surg Edinb 1991;36:331-3.

17. Goenka MK, Mehta SK, Kochhar R, et al. Primary aortoduodenal fistulain a 23-year-old man without an associated aortic aneurysm. Eur J Surg 1993;159:371-2.

18. Jaroch M T, Diehl JT, Zippert AM . Primary aortoduodenal fistula without abdominal aortic aneurysm. Cleve Clin Q 1985;52:579-81.

19. Stefles BC, O'Leary JP. Primary aortoduodenal fistula: a case report and review of the literature. Am Surg 1980;46:121-9.
20. Castilho Jr OT, Santos JS, Peres LC, et al. Fístula aortentérica primária. Rev Cir Vasc Angiol 1995;11:73-6.

21. Yegar RA, Taylor LM Jr, M oneta GL, Edwards JM, et al. Improved results with conventional management of infrarenal aortic infection. J Vasc Surgery 1999;30:76-83.

22. Svensson LG, Crawford ES. Aortic infections. In: Svensson LG Crawford ES, editors. Cardiovascular and vascular disease of the aorta. Philadelphia: WB Saunders; 1997:126-52.

23. Walker WE, Cooley D A, D uncan JM, H allman GL, Ott DA, Reul GJ. The management of aortoduodenal fistula by in situ replacement of the infected abdominal aortic graft. Ann Surg 1987;205:727-32.

24. Chan FY, Crawford ES, Coselli JS, et al. In situ prosthetic graft replacement for mycotic aneurysm of the aorta. Ann Thorac Surg 1989;47:193-203.

25. Torsello G, Sandman W, G eehrt A, et al. In situ replacement of infected vascular prosthesis with rifampin-soaked vascular grafts: early results. J Vasc Surg 1993;17:768-73.

26. Kieffer E, Bahnini A, Koskas F, Ruotolo C, Le Blevec D Plissonnier $D$. In situ allograft replacement of infected infrarena aortic prosthetic grafts: results in forty-three patients. J Vasc Surg 1993;17:349-56.

27. Claget GP, Valentine RJ, H agino RT. Autogenous aortoiliac femoral reconstruction from superficial femoral-popliteal veins feasibility and durability. J Vasc Surg 1997;25:255-70.
. Publ ish ing in for mat ion.

Fábio Lambertini Tozzi, MD, PhD. Assistant Professor, University Hospital, Universidade de São Paulo, São Paulo, Brazil.

Erasmo Simão da Silva, MD, PhD. A ssistant Professor Department of Surgery, Faculty of M edicine, Universidade de São Paulo, São Paulo, Brazil.

Fernando Campos, MD. Assistant Professor, University Hospital, Faculty of M edicine, Universidade de São Paulo, São Paulo, Brazil.

Henrique Oscar de Azevedo Fagundes Neto. Undergraduate student, Faculty of Medicine, Universidade de São Paulo, São Paulo, Brazil.

Marcos Lucon. Undergraduate student, Faculty of M edicine, Universidade de São Paulo, São Paulo, Brazil.

Renato Micelli Lupinacci. Undergraduate student, Faculty of Medicine, Universidade de São Paulo, São Paulo, Brazil.

Sources of funding: $\mathrm{N}$ ot declared

Conflict of interest: $\mathrm{N}$ ot declared

Last received: 23 February 2001

Accepted: 04 May 2001

\section{Address for correspondence}

Erasmo Simão da Silva

Faculdade de Medicina da Universidade de São Paulo

Av. Dr. Arnaldo, 455 - 10 andar - sala 1348

São Paulo/ SP - Brazil - CEP 01246-903

E-mail: ersimao@usp.br

CO PYRIG HT@2001, Associação Paulista de Medicina

RESUMO

CONTEXTO: N a maioria dos casos, as fistulas aortoentericas primárias resultam da erosão da parede do intestino por um aneurisma da aorta abdominal. Poucos pacientes foram descritos com etiologias distintas.

O BJETIVO: O propósito desse trabalho é apresentar uma rara situação clínica, aortite séptica por Salmonella, que evoluiu para a formação de um pseudoaneurisma da aorta que perfurou a transição entre o duodeno eo jejuno.

RELATO DE CASO : U ma paciente de 65 anos, diabética, foi admitida no hospital com bacteremia por Salmonella, que evoluiu para aortite séptica. Um mês após a alta hospitalar a paciente retornou apresentando psedoaneurisma da aorta abdominal infra-renal, que corroeu a transição entre o duodeno e o jejuno originando uma fístula aorto-entérica primária. Foi submetida ao tratamento cirúrgico, sendo realizada ligadura da aorta, remoção do hematoma infectado, enterectomia, êntero-êntero anastomose e enxerto extra-anatômico axilo-bifemoral com prótese de dacron. $\mathrm{Na}$ unidade de terapia intensiva a paciente apresentou parada cardiorrespiratória e óbito.

PALAVRAS-CH AVE: Aortite séptica. Fístula aortoenterica primária. Aneurisma. Pseudoaneurisma. 